\title{
Feeding in the dark: are stonefly nymphs good indicators of reference conditions for cave streams? A case study using gut content analysis in Brazilian quartzite caves
}

\author{
Bárbara Goulart Costa ${ }^{1}$, Rodrigo Lopes Ferreira ${ }^{1}$ and Thais Giovannini Pellegrini2,** \\ ${ }^{1}$ Centro de Estudos em Biologia Subterrânea; Setor de Zoologia Geral; Departamento de Biologia; Universidade \\ Federal de Lavras (UFLA); Campus Universitário; Caixa Postal 3037; CEP: 37200-000; Lavras; Minas Gerais; \\ Brazil. \\ 2 Departamento de Entomologia; Universidade Federal de Lavras (UFLA); Campus Universitário; Caixa Postal \\ 3037; CEP: 37200-000; Lavras; Minas Gerais; Brazil. \\ * Corresponding author: thais.g.pellegrini@gmail.com
}

Received: 26/07/19 Accepted: $11 / 02 / 20$

\begin{abstract}
Feeding in the dark: are stonefly nymphs good indicators of reference conditions for cave streams? A case study using gut content analysis in Brazilian quartzite caves

Benthic macroinvertebrates are considered important bioindicators of water quality, and their distribution is influenced by several factors, including food availability. This feeding is an essential factor for all living beings and determines aspects of temporal and spatial population dynamics and relations between individuals and their respective habitats. The present work aimed to analyze the diet of nymphs of the order Plecoptera associated with quartzite caves located in southern Minas Gerais state, Brazil. The stomach contents of 79 specimens were analyzed, and many were empty (40.5 \%). Among the nymphs with stomach contents, the most frequent content was fine particulate organic matter. The high amount of individuals with empty content may indicate a low tolerance of these organisms to subterranean environments.
\end{abstract}

Key words: subterranean, feeding, Plecoptera, food resources, benthos, bioindicators

\section{RESUMO}

Alimentando na escuridão: ninfas de Plecoptera são boas indicadoras de riachos de caverna em condições de referência? Um estudo de caso utilizando análises de conteúdo estomacal em cavernas quartzíticas Brasileiras

Macroinvertebrados bentônicos são considerados importantes indicadores de qualidade de água, sendo sua distribuição influenciada por fatores como alimentação. Essa preferência é um fator essencial para seres vivos e determina aspectos da dinâmica populacional temporal e espacial. O trabalho teve como objetivo analisar a dieta de ninfas de Plecopteras associadas a cavernas quartzíticas no sul do estado de Minas Gerais. Foi analisado o conteúdo estomacal de 79 espécimes e muitos estavam vazios (40,5\%). Entre as ninfas que possuem conteúdo estomacal, o mais presente foi a matéria orgânica particulada fina. A grande quantidade de indivíduos com o estômago vazio pode indicar baixa tolerância desses organismos a ambientes subterrâneos.

Palavras chave: Subterrâneo, alimentação, Plecoptera, recursos alimentares, bentos, bioindicadores 


\section{INTRODUCTION}

Knowledge of the diversity patterns of water quality bioindicator groups is especially relevant when predicting the effects of global changes on biodiversity (Brito et al., 2018). Among benthic macroinvertebrates, three bioindicator groups stand out: Ephemeroptera, Plecoptera and Trichoptera (EPT). Such organisms are sensitive to environmental changes, relatively easy to identify, have a high number of taxa and are well distributed in tropical low-order streams (Martins et al., 2017; Siegloch et al., 2017). EPT are considered good bioindicators of water quality and therefore are used in the development of Biological indices and metrics to accurately measure the preservation state of rivers and streams (Couceiro et al., 2012). Furthermore, the extrapolation of a given metric developed in one region to another region usually requires adaptations that take into account the physical and geological features of the evaluated regions (Silveira et al., 2005; Couceiro et al., 2012). Thus, before assigning poor habitat quality to low-order streams that do not have such groups of organisms, it is necessary to ensure that these organisms are present in the "reference condition". Here, we define "reference condition" as the "minimally disturbed condition" (MDC), described by Stoddard et al. (2006) as "the biological state at stream sites that show only slight signs of human disturbances".

Plecoptera are generally associated with reference conditions, and their distribution is influenced by food, the physical and chemical conditions of water and other factors (Ferreira et al., 2014). These attributes of the group facilitate ecological measurements of the environmental conditions using data on the occurrence and frequency of organisms (Iliopoulou-Georgudaki et al., 2003) as well as feeding data. Many of these organisms are considered predators (Gallo et al., 2010; López-Rodríguez et al., 2012), but they also act as important shredders and are among the main primary consumers in streams with riparian vegetation (Carvalho \& Uieda, 2009). In addition, many of these species may also serve as prey for other larger aquatic organisms (Loureiro et al., 2015).
Although the exclusive occurrence of Plecoptera in caves is rare (Tierno de Figueroa \& López-Rodríguez, 2010), such organisms can easily access allogenic cave streams. These streams consist of those that run on the surface and then enter the cave environment without sinkholes in their course (Miller, 1996); thus, they are highly connected with the epigeal (surface) environment. However, once these organisms enter the cave environment, they are not necessarily able to establish viable populations due to limitations, mainly in terms of food availability in the subterranean environment. The oligotrophy is a common condition for first-order streams (Fisher \& Likens, 1973). However, in subterranean systems, the photosynthetic production is lacking, and leaf and woody debris inputs are greatly reduced (Culver, 1982; Graening \& Brown, 2003). Such reduction on food supplies may determine an accidental occurrence of mayflies in caves.

We start from the hypothesis that the occurrence of Plecoptera at low frequencies in the subterranean environment does not necessarily mean that allogenic streams have low environmental quality. The aim of this study was then to evaluate whether stonefly nymphs are good indicators of cave streams in reference conditions. To verify whether plecopterans are suitable for MDC subterranean streams, an analysis was performed of the stomach contents of immature specimens collected in three streams associated with quarzitic caves. The occurrence of a high number of organisms with an empty stomach would be an indicator of a low affinity with the study environment.

\section{MATERIALS AND METHODS}

\section{Study area}

Three quartzite caves with allogenic drainage were sampled: Mandembe Cave (S 21 ${ }^{\circ} 32^{\prime} 3810^{\prime \prime}$ W 44 47' 5730"), Serra Grande Cave (S 21 ${ }^{\circ} 33^{\prime}$ $3350^{\prime \prime} \mathrm{W} 44^{\circ} 49^{\prime} 1070^{\prime \prime}$ ) and Toca Cave (S $21^{\circ} 28^{\prime}$ $\left.2400^{\prime \prime} \mathrm{W} 44^{\circ} 40^{\prime} 0200^{\prime \prime}\right)$, which are all located in the southern region of the state of Minas Gerais, Brazil. Although anthropogenic activity occurs in the regions of the municipalities listed above 

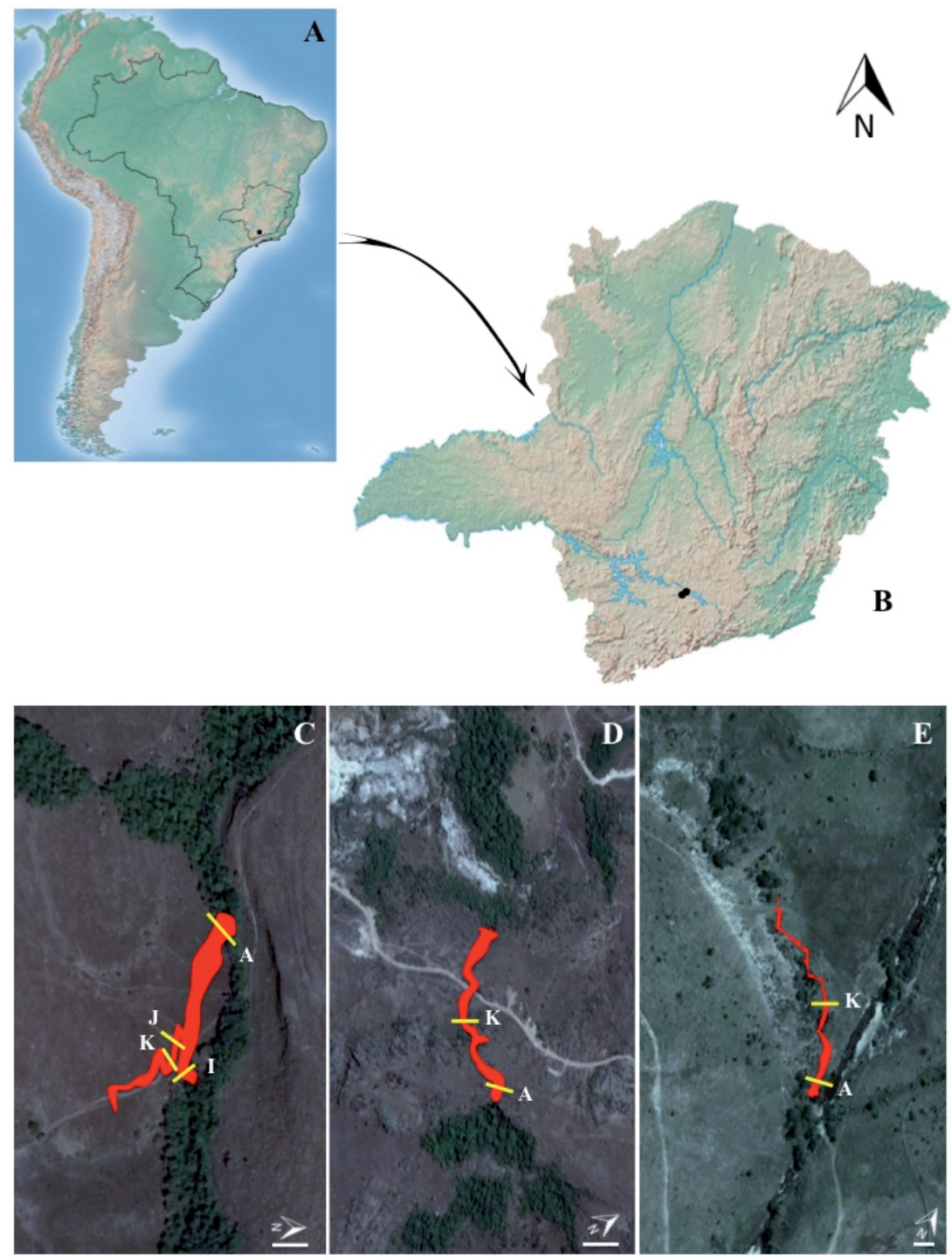

Figure 1. Geographic location of the studied caves; transect A represents the most downstream sampling and $\mathrm{K}$ the upstream one. A) South America with Brazil and Minas Gerais state in detail. B) Zoom in the state of Minas Gerais showing the geographic location of the caves in the Paraná river basin. C) Representation of the Mandembe Cave map; bar scale $=20 \mathrm{~m}$. D) Representation of the Serra Grande Cave map; bar scale $=50 \mathrm{~m}$. E) Representation of the Toca Cave map; bar scale $=20 \mathrm{~m}$. Localização geográfica das cavernas estudadas, o transecto A representa o mais à jusante e o K o mais a montante. A) América do Sul com o Brasil e Minas Gerais em detalhe. B) Zoom no estado de Minas Gerais mostrando a localização geográfica das cavernas na bacia do rio Paraná. C) Representação do mapa da caverna Mandembe; barra de escala $=20 \mathrm{~m}$. D) Representação do mapa da caverna Serra Grande; barra de escala $=50 \mathrm{~m}$. E) Representação do mapa da Gruta da Toca; barra de escala $=20 \mathrm{~m}$.

(livestock and mining), the riparian forests appear to be intact both upstream and downstream of the caves; therefore, these streams can be considered to present a MDC (Fig. 1). During each sampling event, several physical-chemical parameters were recorded (Table 1 ).

\section{Invertebrate sampling and identification}

In each cave, sampling was performed along a 100-meter stretch of the stream divided in 11 transects. In each transect, three samples were collected using a $400-\mathrm{cm}^{2}$ Surber sampler. Since 
Table 1. Physical-chemical characteristics of the three sampled caves during the sampling period. The downstream sampling transect represents the entrance area of the cave, the lowest transect. The medium cave stretch represents the medium transect going forward up the cave stream. The upstream transect represents the last collection transect up the cave stream and the most distant transect from the entrance area. Características físico-químicas das três cavidades amostradas durante o período de amostragem. O transecto de amostragem à jusante representa a área de entrada da caverna, o transecto mais baixo. O trecho médio da caverna representa o transecto médio subindo o riacho da caverna. O transecto a montante representa o último transecto de coleta no córrego da caverna e o transecto mais distante da área de entrada.

\begin{tabular}{|c|c|c|c|c|c|c|c|}
\hline & & & $\begin{array}{c}\text { Temperature } \\
\left({ }^{\circ} \mathrm{C}\right)\end{array}$ & pH & $\begin{array}{c}\text { Conductivity } \\
(\mu \mathrm{s} / \mathrm{cm})\end{array}$ & $\begin{array}{c}\mathrm{O}_{2} \\
(\mathrm{mg} / \mathrm{L})\end{array}$ & $\begin{array}{c}\text { Turbidity } \\
\text { (NTU) }\end{array}$ \\
\hline \multirow{12}{*}{$\begin{array}{l}\text { Mandembe } \\
\text { Cave }\end{array}$} & \multirow{4}{*}{$\begin{array}{l}\text { Down } \\
\text { stream }\end{array}$} & Mean & 18.09 & 4.94 & 0.01 & 5.34 & 0.25 \\
\hline & & $\mathrm{SD}$ & 2.10 & 0.62 & 0 & 0.41 & 0.28 \\
\hline & & Min & 15.21 & 3.53 & 0 & 4.73 & 0.00 \\
\hline & & Max & 20.81 & 5.61 & 0.01 & 5.89 & 0.80 \\
\hline & \multirow{4}{*}{$\begin{array}{l}\text { Medium } \\
\text { cave strech }\end{array}$} & Mean & 18.35 & 4.98 & 0 & 6.67 & 0.90 \\
\hline & & SD & 2.31 & 0.58 & 0 & 3.02 & 1.93 \\
\hline & & Min & 15.04 & 3.74 & 0 & 4.35 & 0.00 \\
\hline & & Max & 21.30 & 5.74 & 0.01 & 15.52 & 6.62 \\
\hline & \multirow{4}{*}{ Up stream } & Mean & 21.78 & 5.02 & 0 & 4.74 & 1.21 \\
\hline & & SD & 0.72 & 0.58 & 0 & 0.91 & 2.29 \\
\hline & & Min & 20.86 & 3.69 & 0 & 3.43 & 0.00 \\
\hline & & Max & 22.60 & 5.75 & 0 & 6.95 & 7.40 \\
\hline \multirow{12}{*}{$\begin{array}{l}\text { Serra } \\
\text { Grande } \\
\text { Cave }\end{array}$} & \multirow{4}{*}{$\begin{array}{l}\text { Down } \\
\text { stream }\end{array}$} & Mean & 17.90 & 4.93 & 0.01 & 6.08 & 1.66 \\
\hline & & $\mathrm{SD}$ & 2.07 & 0.34 & 0.01 & 3.80 & 1.91 \\
\hline & & Min & 14.21 & 4.29 & 0 & 3.91 & 0.00 \\
\hline & & Max & 19.92 & 5.41 & 0.02 & 17.31 & 6.00 \\
\hline & \multirow{4}{*}{$\begin{array}{l}\text { Medium } \\
\text { cave strech }\end{array}$} & Mean & 18.26 & 5.18 & 0 & 5.18 & 1.30 \\
\hline & & $\mathrm{SD}$ & 1.86 & 0.27 & 0 & 0.86 & 1.49 \\
\hline & & Min & 14.95 & 4.74 & 0 & 4.12 & 0.00 \\
\hline & & Max & 19.80 & 5.51 & 0 & 6.68 & 4.20 \\
\hline & \multirow{4}{*}{ Up stream } & Mean & 18.49 & 5.29 & 0 & 5.11 & 1.47 \\
\hline & & $\mathrm{SD}$ & 1.53 & 0.22 & 0 & 0.62 & 1.76 \\
\hline & & Min & 16.10 & 4.74 & 0 & 4.02 & 0.00 \\
\hline & & Max & 20.00 & 5.51 & 0.01 & 6.03 & 4.60 \\
\hline \multirow{12}{*}{$\begin{array}{l}\text { Gruta da } \\
\text { Toca Cave }\end{array}$} & \multirow{4}{*}{$\begin{array}{l}\text { Down } \\
\text { stream }\end{array}$} & Mean & 20.58 & 4.70 & 0.01 & 5.04 & 2.88 \\
\hline & & $\mathrm{SD}$ & 2.76 & 0.40 & 0 & 0.58 & 2.69 \\
\hline & & Min & 17.20 & 4.04 & 0.01 & 4.02 & 0.00 \\
\hline & & Max & 27.75 & 5.37 & 0.02 & 6.11 & 7.50 \\
\hline & \multirow{4}{*}{$\begin{array}{l}\text { Medium } \\
\text { cave strech }\end{array}$} & Mean & 21.14 & 4.39 & 0.01 & 5.16 & 2.62 \\
\hline & & $\mathrm{SD}$ & 2.39 & 1.19 & 0 & 0.80 & 2.77 \\
\hline & & Min & 18.96 & 0.95 & 0 & 3.93 & 0.00 \\
\hline & & Max & 27.75 & 5.47 & 0.02 & 6.51 & 8.70 \\
\hline & \multirow{4}{*}{ Up stream } & Mean & 21.39 & 4.78 & 0.01 & 4.57 & 3.73 \\
\hline & & $\mathrm{SD}$ & 2.29 & 0.32 & 0.02 & 0.47 & 3.51 \\
\hline & & Min & 19.50 & 4.33 & 0 & 3.71 & 0.00 \\
\hline & & Max & 27.75 & 5.49 & 0.06 & 5.29 & 12.10 \\
\hline
\end{tabular}


the Mandembe Cave main stream has less than 100 meters in length, two transect were positioned in a lateral tributary. The sampling was repeated monthly, for a total of 11 sampling events in each cave. From the samples obtained in the field, Plecoptera were separated from the other species of benthic organisms using a stereomicroscope (ZEISS - STEMI 2000). The organisms were then identified to the genus level. The identification was performed using the taxonomic key (Mugnai et al., 2010) and a stereomicroscope (ZEISS - STEMI 2000).

\section{Gut content analysis}

To assess the gut contents, each specimen had its abdomen dissected and gut opened with the aid of a scalpel and entomological pins. All gut contents were removed, mounted on slides and coverslips, and then analyzed under a microscope. The gut contents were classified into four categories: $i$ ) FPOM (fine particulate organic matter, represented by fragmented pieces smaller than $1 \mathrm{~mm}$ ); ii) CPOM (coarse particulate organic matter, represented by fragmented pieces larger than $1 \mathrm{~mm}$ ); iii) PT (plant tissue); and iii) AT (animal tissue) according to the categorization proposed by Azzouz \& Sánchez-Ortega (2000). Plant tissue and animal tissue were distinguished by cell type under the microscope. The gut contents were analyzed for the frequency of occurrence of each food item (independently of their size), which is the most efficient method of qualitatively analyzing diets (Azzouz \& Sánchez-Ortega, 2000). In this way the same individual could present more than one category of food item classification. Based on the gut content analysis of all specimens, a list was prepared with the various types of food with records of the presence or absence of food items in the gut of each specimen analyzed. After analyzing all specimens, the proportion of organisms containing one or more items of a given type of food was calculated as the frequency of occurrence of that type of food.

We investigated the existence of differences in the stoneflies nutritional quality performing a Mann-Whitney test, using wilcox.test function, in the stats package in R program ( $\mathrm{R}$ Core Team, 2018). Finally, we represented the stoneflies gut contents spatially, according to each cave collecting transect.

\section{RESULTS}

A total of 85 Plecoptera individuals were found in the caves, which represent approximately $4.3 \%$ of the total EPT found in the cave streams under study (Table 2). The gut contents were analyzed for 79 Plecoptera individuals. For the others six specimens dissection and gut opening was not possible due to their very small size or due to a high degree of body tissues damage. Among the total of Plecoptera, 42 were collected in the Mandembe Cave, 14 in the Serra Grande Cave, and 29 in the Toca Cave. Of this total, 34 belonged to the family Perlidae and were distributed in the genera Kempnya, Anacroneuria and Macrogynoplax, and 51 belonged to the family Gripopterygidae and were distributed in the genera Tupiperla, Gripopteryx and Paragripopteryx.

None of the specimens analyzed had CPOM or PT in their gut. Of all the analyzed individuals, the gut was empty in 32 individuals, which represented approximately $40.5 \%$ of the total analyzed individuals. Among the individuals with an empty gut, 20 belonged to the family Gripopterygidae, and only 12 belonged to the family Perlidae. The most widely distributed food item among the analyzed organisms was FPOM (Table 3 , Fig. 2), which was present in approximately $59.4 \%$ of the analyzed organisms. For all individuals in which animal tissue was found, there was also FPOM. Among the food items found, it was possible to identify organisms of the families Simuliidae and Chironomidae, both belonging to the order Diptera.

The stoneflies' body size was not related to their nutritional quality content. The spatial distribution of the stoneflies in the three caves did not show a gradient from the entrance to the deeper caves' regions (Fig. 3). In Mandembe Cave, it was possible to observe an increase in the FPOM gut content in the transects close to cave entrance. The Serra Grande Cave stoneflies showed a bigger amount of FPOM in the transect close to entrances, and such content became less abundant downstream. Finally, in Toca Cave it was possible to see an increase of 
Table 2. Abundance of the EPT genera in each cave. Abundância de gêneros de EPT em cada caverna.

\begin{tabular}{|c|c|c|c|}
\hline & Gruta da Toca & Gruta Mandembe & Gruta Serra Grande \\
\hline \multicolumn{4}{|c|}{ EPHEMEROPTERA } \\
\hline \multicolumn{4}{|l|}{ Baetidae } \\
\hline Adebrotus & & 4 & \\
\hline Americabaetis & & 8 & 5 \\
\hline Apobaetis & & 1 & 1 \\
\hline Baetodes & & 7 & \\
\hline Cloeodes & 12 & 18 & 12 \\
\hline Paracloeodes & 1 & 11 & \\
\hline Tupiara & & 1 & \\
\hline Waltzoyphius & 4 & 56 & \\
\hline Zelusia & 1 & 78 & 14 \\
\hline \multicolumn{4}{|l|}{ Caenidae } \\
\hline Caenis & 1 & & \\
\hline \multicolumn{4}{|l|}{ Leptohyphidae } \\
\hline Tricorythopsis & & 4 & \\
\hline \multicolumn{4}{|l|}{ Leptophlebiidae } \\
\hline Askola & 1 & 286 & 80 \\
\hline Hagenulopsis & & 188 & 36 \\
\hline Massartella & & 23 & \\
\hline Simothraulopsis & & 338 & 11 \\
\hline \multicolumn{4}{|l|}{ PLECOPTERA } \\
\hline \multicolumn{4}{|l|}{ Gripopterygidae } \\
\hline Gripopteryx & 1 & 3 & \\
\hline Paragripopteryx & 3 & 5 & \\
\hline Tupiperla & 14 & 23 & 2 \\
\hline \multicolumn{4}{|l|}{ Perlidae } \\
\hline Anacroneuria & 9 & 1 & 5 \\
\hline Kempnyia & 2 & 10 & 6 \\
\hline Macrogynoplax & & & 1 \\
\hline \multicolumn{4}{|l|}{ TRICHOPTERA } \\
\hline \multicolumn{4}{|c|}{ Anomalopsychidae } \\
\hline Cotulma & & & 2 \\
\hline \multicolumn{4}{|l|}{ Calamoceratidae } \\
\hline Phylloicus & 43 & 23 & 11 \\
\hline
\end{tabular}


Table 2. (cont.)

\section{Ecnomidae}

Austrotinodes

1

Helichopsychidae

Helicopsyche

Hydrobiosidae

Atopsyche

Hydrophilidae

Derallus

Hydropsychidae

Leptonema

16

Macrostemum

Smicridea

16

6

Hydroptilidae

Alisotrichia

14

86

10

Leucotrichia

2

1

Neotrichia

211

34

Oxyethira

Leptoceridae

Grumichella

Nectopsyche

1

23

10

Nectopsyche

Notalina

Oecetis

3

1

13

14

1

Triplectides

7

Odontoceridae

Barypenthus

Marilia

Odontoceridae

Barypenthus

Marilia

1

Polycentropodidae

Cyrnellus

Polycentropus 
Table 3. Food item frequency for each stonefly nymph genus. FPOM: fine particulate organic matter; AT: animal tissue; PT: plant tissue; CPOM: coarse particulate organic matter. Since the same individual presented more than one food item classification, the sum of all item categories exceeded $100 \%$. Frequência de itens alimentares para cada gênero de ninfa de Plecoptera. FPOM: matéria orgânica particulada fina; AT: tecido animal; PT: tecido vegetal; CPOM:, matéria orgânica particulada grossa. Como ocorreu mais de uma classificação de item alimentar para mesmo individuo, a soma de todas as categorias ultrapassou $100 \%$.

\begin{tabular}{llccccc}
\hline Family & Genera & Empty & FPOM & AT & PT & CPOM \\
\hline \multirow{3}{*}{ Gripopterygidae } & Tupiperla & 16 & 20 & 0 & 0 & 0 \\
& Gripopteryx & 2 & 2 & 0 & 0 & 0 \\
& Paragripopteryx & 2 & 6 & 0 & 0 & 0 \\
\hline \multirow{3}{*}{ Perlidae } & Kempniya & 4 & 12 & 7 & 0 & 0 \\
& Anacroneuria & 8 & 6 & 0 & 0 & 0 \\
& Macrogynoplax & 0 & 1 & 0 & 0 & 0 \\
\hline \multirow{2}{*}{ Total / percentage } & & $\mathbf{3 2}$ & $\mathbf{4 7}$ & $\mathbf{7}$ & $\mathbf{0}$ & $\mathbf{0}$ \\
\hline
\end{tabular}

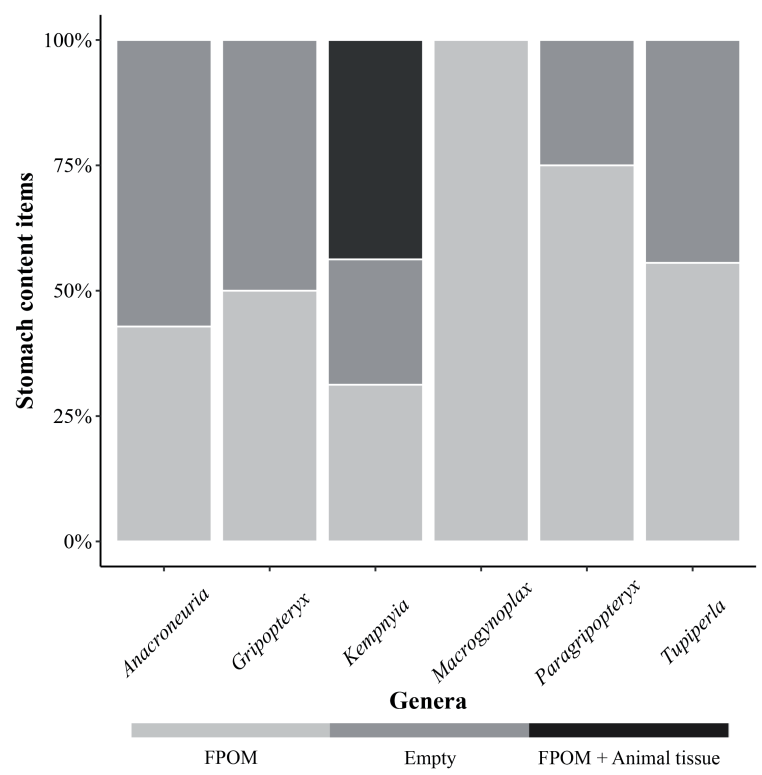

Figure 2. Percentage of the food items ingested by each stonefly nymph genus. Porcentagem dos itens alimentares ingeridos por cada gênero de ninfa de Plecoptera.

FPOM in the gut content in the last three collecting transects, located downstream in the cave.

\section{DISCUSSION}

In this work, only few individuals of Plecoptera were found when compared to other EPT groups found in the same caves. The proportion of these organisms tends to be much higher in surface aquatic invertebrate communities (Azzouz \& Sánchez-Ortega, 2000; Kikuchi \& Uieda, 2005; Loureiro et al., 2015). While some Trichoptera and Ephemeroptera are more diverse and tolerant to a wider range of conditions, Plecoptera are found only in waters with a higher quality (Galdean et al., 2000). In general, the fact that caves are environments with limited resources generates a longitudinal colonization gradient, where the entry zones are richer and more abundant in invertebrates compared to more inner areas (Watson, 2010; Gomes et al., 2009). However, this pattern was not observed in the studied caves. Although a low abundance of predatory organisms, such as Perlidae, was expected (Vannote et al., 1980; Watson, 2010), the abundance found was extremely low. The lower richness of cave communities compared to epigean communities has been widely reported in the literature (Gomes et al., 2009; Prous et al., 2004). The peculiar characteristics of these environments hinder their colonization (Pipan \& Culver, 2012); therefore, the aquatic communities in caves often represent subsets of the communities associated with surface streams (Gunn et al., 2000; Watson, 2010).

Although it is considered an oligotrophic environment, the Mandembe Cave had the largest 
number of Plecoptera individuals. Most likely, greater colonization by Plecoptera was observed in this cave because it is the smallest cave analyzed in this study and consequently is under a greater influence of the surface environment. The colonization of lotic cave environments often occurs through drift (Kohler, 1985) because the environment presents low food availability and total absence of light, many of these organisms release themselves into the current to escape from caves and find a more favorable environment (Death, 1989). Thus, larger caves favor this behavior, and few individuals actually settle in the caves. In addition, individuals of Plecoptera are sensitive to disturbances, and their occurrence is dependent on the quality of the aquatic environment (Ferreira et al., 2014). Thus, the search for more favorable environments becomes even more evident.

The availability of organic matter within the lotic cave environment is dependent on the influx of allochthonous resources, which in turn are directly related to the flow regime of the cave stream. Given the slow flow of the streams analyzed here, the influx of organic matter into the caves is low, which severely hinders the feeding of Plecoptera. Therefore, the caves may eventually become transitional environments for Plecoptera in search of an environment with greater food availability. In addition, few individuals were found with food items in their guts, and in a large proportion, their guts were empty.

The fact that the environment is oligotrophic does not necessarily imply a high incidence of organisms with an empty gut. A study conducted in Himalayan high-altitude lagoons, which represent environments that are also considered extremely oligotrophic, did not find as high a proportion of individuals with empty guts, and only approximately $11 \%$ of the evaluated Capniidae (Plecoptera) had empty guts (Boggero et al.,
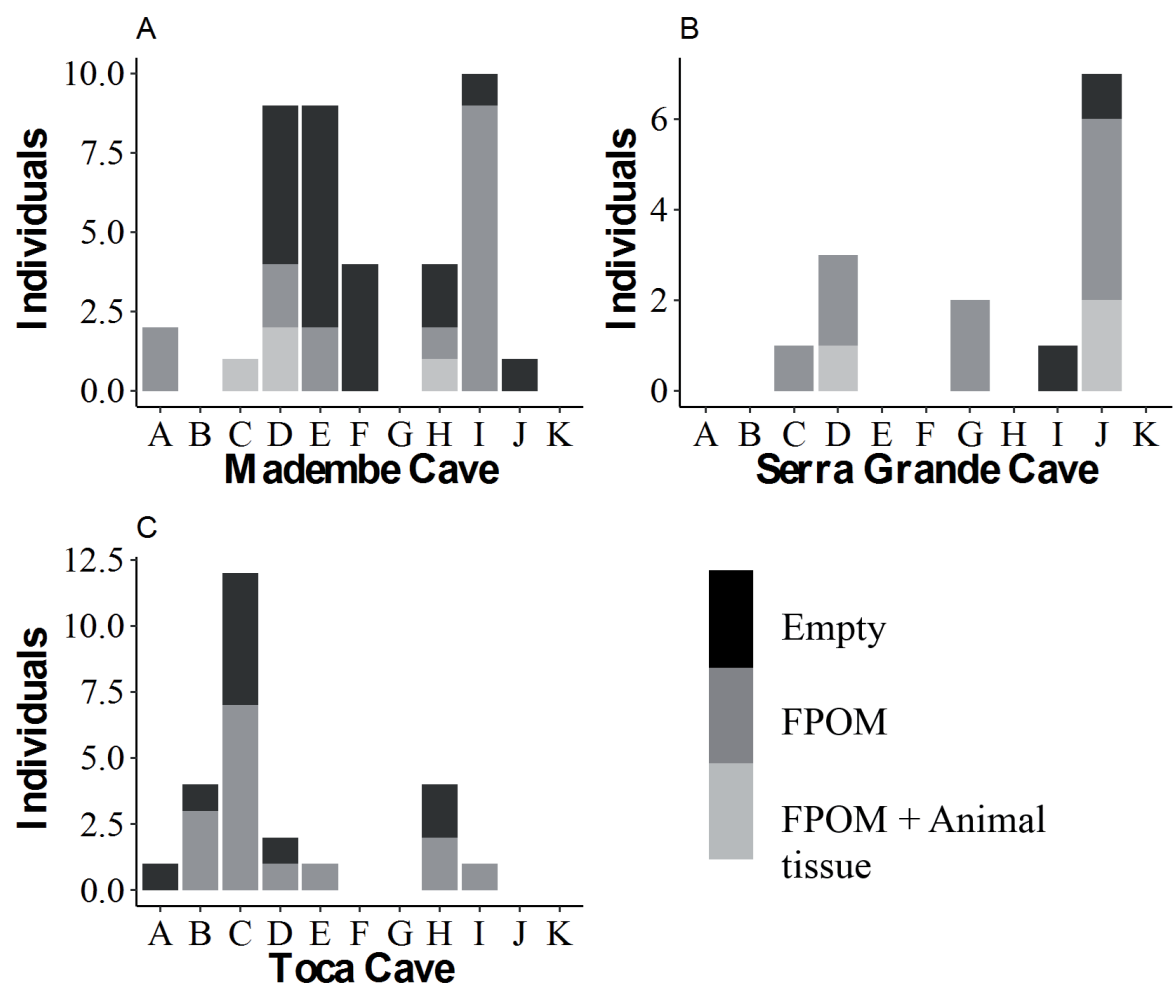

Empty

FPOM

FPOM + Animal

tissue

Figure 3. Spatial representation of the stoneflies gut contents analyses found in each cave. Transect A represents the most downstream collection site of each cave and transect K upstream. Representação espacial do conteúdo estomacal dos plecópteras encontrados em cada caverna. O ponto A representa o local de coleta mais à jusante de cada caverna e o ponto Ko mais a montante. 
2014). The cave stonefly Protonemura gevi (Tierno-de-Figueroa \& López-Rodríguez, 2010) adapted to the subterranean environment, has also a higher rate of empty guts, of approximately $39 \%$ (López-Rodríguez \& Tierno de Figueroa, 2015). Therefore, other factors must have contributed to the high occurrence of organisms without gut contents in the caves analyzed here. Stoneflies are opportunistic, and the food ingested may vary depending on the species developmental stage and whether its preferred food item is in low abundance (Stewart, 1984). The nymphs can even spend periods without feeding, which may occur given the lack of prey or during the larval molting stages. In addition, predators (represented by Perlidae) have periods during which they do not feed either because of a lack of prey availability or during the molting period (Ferreira, 1996; Magni-Darwich et al., 1999). The predation rate of Plecoptera decreases as environmental conditions become more stressful (Thomsom et al., 2002). Among the Perlidae, only individuals of the genus Kempnyia had prey in their gut contents, which does not necessarily mean that the organisms have been feeding inside the caves. Given the small length of the caves, the nymphs may have fed at the surface environment before their collection inside caves. Predation occurs via the detection of prey by a combination of mechanical, chemo sensitive and visual structures (Peckarsky, 1982); thus, predation is impaired in an environment with a total absence of light.

Regarding the stoneflies that did feed, most of them had FPOM in the gut contents, confirming that Plecoptera contribute to the fragmentation of the leaf detritus in the streams (Graça, 2001; Loureiro et al., 2015; Azzouz \& Sánchez-Ortega, 2000). In contrast, among the cave $P$. gevi specimens, the main food item found was CPOM (López-Rodríguez \& Tierno-de-Figueroa, 2015). The adaptation of $P$. gevi to the cave environment probably provides it with differentiated structures that enable more efficient access to food resources in an aphotic and oligotrophic environment. On the other hand, in high-altitude oligotrophic environments, the family Capniidae, which is generally categorized as collector-gatherer and shredder, becomes mainly a collector-gatherer and feeds on FPOM due to the low CPOM availability (Bogge- ro et al., 2014). Such changes in the proportions of food items are expected in the surface stoneflies that access the caves, and the large proportion of individuals with an empty gut provide a strong indication of the low adaptations of stoneflies to the subterranean environment.

A study on the dietary habits of Gripopterygidae in the Northern Hemisphere revealed that the species from this family are herbivore-detritivores (Yule, 1986). The study also reports a changing in the feeding habits with the increasing nymphal size. Larger species consume a higher quality nutritional diet in terms of protein and calorific content, with larger amounts of filamentous green algae and diatoms in their guts. FPOM is found in all analyzed species, however such item was considered the least nutritionally valuable of the food items (Yule, 1986). Regardless the body size, the most frequently food item found among the stoneflies individuals analyzed in this study was the FPOM. However, it is worth mentioning that filamentous green algae and diatoms are not expected to be found in the stoneflies guts due to the complete darkness of the caves.

The spatial pattern of gut content found in Mandembe Cave clearly represents the oligotrophy of the lateral tributary, which is more isolated from the surface. The Serra Grande Cave was the only one that showed a gradient of reduction of gut content from the entrance towards deeper regions of the cave. This pattern was expected due to the intense gradient found in caves following the light that became totally absent in profound cave regions (Watson, 2010). The smaller amount of FPOM found in the transects closer to the surface in Toca Cave ( $\mathrm{J}$ and $\mathrm{K}$ ) occurs probably because those transects are about 300 meters far from the entrance while in Serra Grande cave it is about 50 meters far. The increase in FPOM in the downstream transects ( $\mathrm{A}, \mathrm{B}$ and $\mathrm{C}$ ) is once again due to a submerged bat guano deposit found between the transects $\mathrm{B}$ and $\mathrm{C}$ in this cave. Bat guano is an important organic impute resource in caves, which can influence in the aquatic fauna densities (Fenolio et al., 2005). The lack of a similar pattern for the three caves is expected, since subterranean environments are known to be unique (when compared to each other) due to physical (structural), hydrological 
and biological distinctions between them (Pellegrini et al., 2018).

Although the existence of the true cave Plecoptera $P$. gevi, the analyzed quartzite caves were not a favorable environment for colonization by this group. The results of this study show that Plecoptera should not be included in biological indices for measuring habitat quality in caves because they have low affinity with the subterranean environment. Nevertheless, further studies covering a larger number of caves are needed to provide a better understanding of this family dynamics in this highly peculiar environment.

\section{ACKNOWLEDGEMENTS}

This work was supported by the Centro de Estudos em Biologia Subterrânea team, who collected the data. We thank Lucas Del Sarto for making the maps. Authors are grateful to the Coordenação de Aperfeiçoamento de Pessoal de Nível Superior (CAPES), the National Council of Technological and Scientific Development (CNPq), Vale S.A. and Fundação de Amparo à Pesquisa do Estado de Minas Gerais (FAPEMIG) for the research financial support. Authors are also grateful to the anonymous reviewers for their suggestions and valuable comments that significantly improved the text.

\section{REFERENCES}

AZZOUZ, M., \& A. SÁNCHEZ-ORTEGA. 2000. Feeding of the nymphs of nine stonefly species (Insecta: Plecoptera) from North Africa (Rif Mountains, Morocco). Zoologica Baetica, 11: 35-50.

BOGGERO, A., T. BO, S. ZAUPA, \& S. FENOGLIO. 2014. Feeding on the roof of the world: the first gut content analysis of very high altitude Plecoptera. Entomologica Fennica, 25(4): 220-224.

CALLISTO, M., M. MORETTI, \& M. GOULART. 2001. Macroinvertebrados bentônicos como ferramenta para avaliar a saúde de riachos. Revista Brasileira de Recursos Hídricos, 6(1): 71-82.

CULVER, D. C. 1982. Cave Life: Evolution and Ecology. Harvard University Press, Cam- bridge, Massachusetts, US.

DE CARVALHO, E. M. \& V. S. UIEDA. 2009. Diet of invertebrates sampled in leaf-bags incubated in a tropical headwater stream. Zoologia, 26(4): 694-704.

COUCEIRO, S. R. M., N. HAMADA, B. R. FORSBERG, T. P. PIMENTEL \& S. L. B. LUZ. 2012. A macroinvertebrate multimetric index to evaluate the biological condition of streams in the Central Amazon region of Brazil. Ecological Indicators, 18: 118-125.

CHESHIRE, K. I. M., L. U. Z. BOYERO \& R. G. PEARSON. 2005. Food webs in tropical Australian streams: shredders are not scarce. Freshwater Biology, 50(5): 748-769.

DEATH, R. G. 1989. The effect of a cave on benthic invertebrate communities in a South Island stream. New Zealand Natural Sciences, 16: 67-78.

FENOLIO, D. B., GRAENING, G. O., COLLIER, B. A., \& J. F. STOUT. 2005. Coprophagy in a cave-adapted salamander; the importance of bat guano examined through nutritional and stable isotope analyses. Proceedings of the Royal Society B: Biological Sciences, 273(1585): 439-443.

FERREIRA, W. R., R. LIGEIRO, D. R. MACEDO, R. M. HUGHES, P. R. KAUFMANN, L. G. OLIVEIRA, G. LEANDRO \& M. CALLISTO. 2014. Importance of environmental factors for the richness and distribution of benthic macroinvertebrates in tropical headwater streams. Freshwater Science, 33: 860-871.

FERREIRA, R. L., \& L. C. S. HORTA. 2001. Natural and human impacts on invertebrate communities in Brazilian caves. Revista Brasileira de Biologia, 61(1): 7-17.

FOCHETTI, R., \& J. M. TIERNO DE FIGUEROA. 2008. Global diversity of stoneflies (Plecoptera; Insecta) in freshwater. In: Freshwater Animal Diversity Assessment (Developments in Hydrobiology) Balian, E. V., Lévêque, C., Segers, H., \& K. Martens, (ed.), 198: 365-377.

GALDEAN, N., M. CALLISTO, \& F. A. R. BARBOSA. 2000. Lotic ecosystems of Serra do Cipó, southeast Brazil: water quality and a tentative classification based on the benthic 
macroinvertebrate community. Aquatic Ecosystem Health \& Management, 3(4): 545-552.

GALLO, L., L. LUCADAMO, M. J. L. RODRÍGUEZ, J. M. TIERNO DE FIGUEROA, T. BO, \& S. FENOGLIO. 2010. Nymphal diet of two Perlidae species (Insecta: Plecoptera) in Southern Apennines (Calabria, Italy). Boletín de la SEA, 46: 363-366.

GOMES, F. T. D. M. C., R. L. FERREIRA, \& C. M. JACOBI. 2001. Comunidade de artrópodes de uma caverna calcária em área de mineração: composição e estrutura. Revista Brasileira de Zoociências, 3(2): 77-96

GRAÇA, M. A. S., R. C. F. FERREIRA \& C. N. COIMBRA. 2001. Litter processing along a stream gradient: the role of invertebrates and decomposers. Journal of the North American Benthological Society, 20(3): 408-420.

GRAENING, G. O. \& A.V. BROWN. 2007. Ecosystem dynamics and pollution effects in an Ozark cave stream. Journal of the American Water Resources Association, 39(6): 1497-1507.

GUNN, J., HARDWICK, P. \& P. J. WOOD. 2000. The invertebrate community of the Peak-Speedwell cave system, Derbyshire, England-pressures and considerations for conservation management. Conservação Aquática: Ecossistemas Marinhos e de Água Doce, 10(5): 353-369.

ILIOPOULOU-GEORGUDAKI, J., V. KANTZARIS, P. KATHARIOS, P. KASPIRIS, T. GEORGIADIS \& B. MONTESANTOU. 2003. An application of different bioindicators for assessing water quality: a case study in the rivers Alfeios and Pineios (Peloponnisos, Greece). Ecological Indicator, 2(4): 345-360.

KOHLER, S. L. 1985. Identification of stream drift mechanisms: an experimental and observational approach. Ecology, 66(6): 1749-1761.

KIKUCHI, R. M., \& V. S. UIEDA. 2005. Composição e distribuição dos macroinvertebrados em diferentes substratos de fundo de um riacho no município de Itatinga, São Paulo, Brasil. Entomologia y Vectores, 12(2): 193-231.

LÓPEZ-RODRÍGUEZ, M. J., C. E. TRENZADO, J. M. TIERNO-DE-FIGUEROA \& A.
SANZ. 2012. Digestive enzyme activity and trophic behavior in two predator aquatic insects (Plecoptera, Perlidae). A comparative study. Bioquímica Comparada e Fisiologia Parte A: Fisiologia Molecular e Integrativa, 162(1): 31-35.

LOUREIRO, R. C., F. M. URBIM, G. TONELLO, R. M. RESTELLO \& L. U. HEPP. 2015. Larvas de Gripopterygidae (Insecta: Plecoptera) associadas a fragmentação de detritos foliares em riachos subtropicais. Perspectiva, 39(145): 61-71.

MAGNI-DARWICH, S., Y. B. ALENCAR \& N. HAMADA. 1999. Stomach content analysis of potential predators of Simuliidae (Diptera: Nematocera) in two lowland forest streams, Central Amazonia, Brazil. Anais da Sociedade Entomologica do Brasil, 28(2): 327-332. MILLER, T. E. 1996. Geologic and hydrologic controls on karst and cave development in Belize. Journal of Cave and Karst Studies, 58(2): 100-120.

MUGNAI, R., J. L. NESSIMIAN \& D. F. BAPTISTA. 2010. Manual de identificação de macroinvertebrados aquáticos do Estado do Rio de Janeiro: para atividades técnicas, de ensino e treinamento em programas de avaliação da qualidade ecológica dos ecossistemas lóticos. Technical Books Editora, Rio de Janeiro, Brazil.

HAMADA, N. 2004. A key to Brazilian genera of Plecoptera (Insecta) based on nymphs. Zootaxa, 651: 1-15.

PECKARSKY, B. L. 1982. Aquatic insect predator-prey relations. BioScience, 32(4): 261-266.

PELLEGRINI, T. G., P. S. POMPEU \& R. L. FERREIRA. 2018. Cave benthic invertebrates in south-eastern Brazil: are there 'key' factors structuring such communities? Marine and Freshwater Research, 69(11): 1762-1770.

PIPAN, T. \& D. C. CULVER. 2012. Convergence and divergence in the subterranean realm: a reassessment. Biological Journal of the Linnean Society, 107(1): 1-14.

PROUS, X., R. L. FERREIRA \& R. P. MARTINS. 2004. Ecotone delimitation: Epigean-hypogean transition in cave ecosystems. Austral Ecology, 29(4): 374-382.

$\mathrm{R}$ CORE TEAM. 2018. R: A language and 
environment for statistical computing. $R$ Foundation for Statistical Computing, Vienna, Austria. URL https://www.R-project.org.

SILVEIRA, M. P. 2004. Aplicação do biomonitoramento para avaliação da qualidade da água em rios. Embrapa Meio Ambiente. Documento. Empresa Brasileira de Pesquisa Agropecuária. Brasil

SILVEIRA, M. P., D. F. BAPTISTA, D. F. BUSS, J. L. NESSIMIAN \& M. EGLER. 2005. Application of biological measures for stream integrity assessment in South-East Brazil. Environmental Monitoring and Assessment, 101(1-3): 117-128.

STODDARD, J. L., D. P. LARSEN, C. P. HAWKINS, R. K. JOHNSON \& R. H. NORRIS. 2006. Setting expectations for the ecological condition of streams: the concept of reference condition. Ecological Applica- tions, 16(4): 1267-1276.

TIERNO-DE-FIGUEROA, J. M. \& M. J. LÓPEZ-RODRÍGUEZ. 2010. Protonemura gevi sp. n., a cavernicolous new species of stonefly (Insecta: Plecoptera). Zootaxa, 2365: 48-54.

VANNOTE, R. L., G. W. MINSHALL, K. W. CUMMINS, J. R. SEDELL \& C. E. CUSHING. 1980. The river continuum concept. Canadian journal of fisheries and aquatic sciences, 37(1): 130-137.

WATSON, T. N. 2010. The structuring of aquatic macroinvertebrate communities within cave streams. M.Sc. Thesis, University of Canterbury, Christchurch, New Zealand.

YULE, C. 1986. Comparison of the dietary habits of six species of Dinotoperla (Plecoptera: Gripopterygidae) in Victoria. Marine and Freshwater Research, 37(2): 121-127. 